\title{
INVOLUTION OF THE LEFT LIVER IN THE NEWBORN AND ITS RELATIONSHIP TO PHYSIOLOGICAL ICTERUS \\ BY
}

\author{
JOHN L. EMERY \\ From the Department of Pathology, Children's Hospital, Sheffield
}

(RECEIVED FOR PUBLICATION MAY 21, 1953)

It was recently shown (Emery, 1952) that in approximately a third of children dying within the first few days of birth there was microscopic evidence of degeneration of parenchymal cells in the left physiological lobe of the liver. This change was not seen in stillborn children and was seen with increasing rareness in older children. It was suggested then that the changes were due to cessation of the flow of placental blood through the left liver at birth.

The importance of the microscopic changes in the liver should be reflected in gross changes in size of the different lobes of the liver at birth, and the present communication records a study of gross changes in the liver associated with birth.

\section{Materiak and Methods}

The material consisted of the livers from a consecutive series of 100 necropsies on premature stillborn infants and children dying within the first 12 weeks of birth.

Owing to the high incidence of fatty and other changes in the right liver associated with intra-uterine anoxia and placental disease found in mature stillbirths, it was felt that such livers could not be taken as representative of the normal liver at the time of birth. For this reason mature stillborns were excluded from the series reported here.

The livers were removed from the body with minimal manipulation and, after examination of the gall-bladder and ductus venosus, the liver was divided into two parts along the line of division of the physiological left and right lobes (Cantlie, 1898; Mall, 1906). The cut was made through the mid-part of the attachment of the gallbladder to the liver. The anterior edge of the liver was cut directly opposite the tip of the gall-bladder and the incision carried obliquely backwards to the most anterior aspect of the hepatic vein where it entered the vena cava. The cut surface so produced is almost bloodless in contrast to that resulting from cuts in other parts of the liver.

The lobes were then weighed and the ratio of the weight of the right to the left lobe obtained, i.e. the right lobe weight was divided by the weight of the left lobe.

The maturity of the premature stillborns was assessed by a combination of the known date of the mother's last menses and the crown-rump length of the infant based on the data of Scammon and Calkins (1929) and Streeter (1920).

\section{Results}

The average ratio was found to be constant in the last few months of intra-uterine life, the ratio being 0.89 , i.e. the left lobe being about a tenth larger than the right (Table 1 ). The ratio was found

\section{TABLE 1}

THE RATIO OF THE WEIGHTS OF THE RIGHT AND LEFT LIVERS IN INFANTS OF DIFFERENT AGE GROUPS

\begin{tabular}{|c|c|c|c|}
\hline Age of Child & & Ratio of R.:L. Lobes & Number of Cases \\
\hline \multicolumn{2}{|l|}{$\begin{array}{l}5 \text { to } 7 \text { lunar months } \\
8 \text { lunar months } \\
9 \text { lunar months } \\
\text { Birth to } 12 \text { hours } \\
13 \text { to } 24 \text { hours } \\
25 \text { to } 48 \text { hours } \\
3 \text {, } 4 \text { and } 5 \text { days } \\
6 \text { to } 14 \text { days } \\
15 \text { to } 21 \text { days } \\
3 \text { to } 6 \text { weeks } \\
7 \text { to } 12 \text { weeks }\end{array}$} & $\begin{array}{l}0 \cdot 89 \\
0 \cdot 87 \\
0 \cdot 89 \\
0 \cdot 89 \\
1 \cdot 00 \\
1 \cdot 04 \\
1 \cdot 02 \\
1 \cdot 16 \\
1 \cdot 11 \\
1 \cdot 12 \\
1 \cdot 14\end{array}$ & $\begin{array}{r}7 \\
6 \\
6 \\
14 \\
3 \\
9 \\
10 \\
13 \\
7 \\
11 \\
14\end{array}$ \\
\hline & & & Total \\
\hline
\end{tabular}

to be unchanged in children dying within 12 hours of birth.

Within 48 hours of birth a marked change in ratio of the lobes occurs, the right lobe becoming larger than the left; the ratio thus becomes almost exactly the reverse of the foetal ratio. This change is completed by the end of the first week. From this time the ratio of the lobes throughout the rest of early infancy seems to remain fairly constant. This rapid change over in dominance of the left lobe in utero to the right lobe in early infancy is illustrated graphically in Fig. 1.

For the purpose of statistical study the cases were grouped as in Table 2 and analysed on the numbers of livers showing right lobe preponderance. The change over in dominance of the lobes was significant $\left(\chi^{2}=38 \cdot 62\right)$ and the probability of the findings being due to chance less than one in a thousand. 


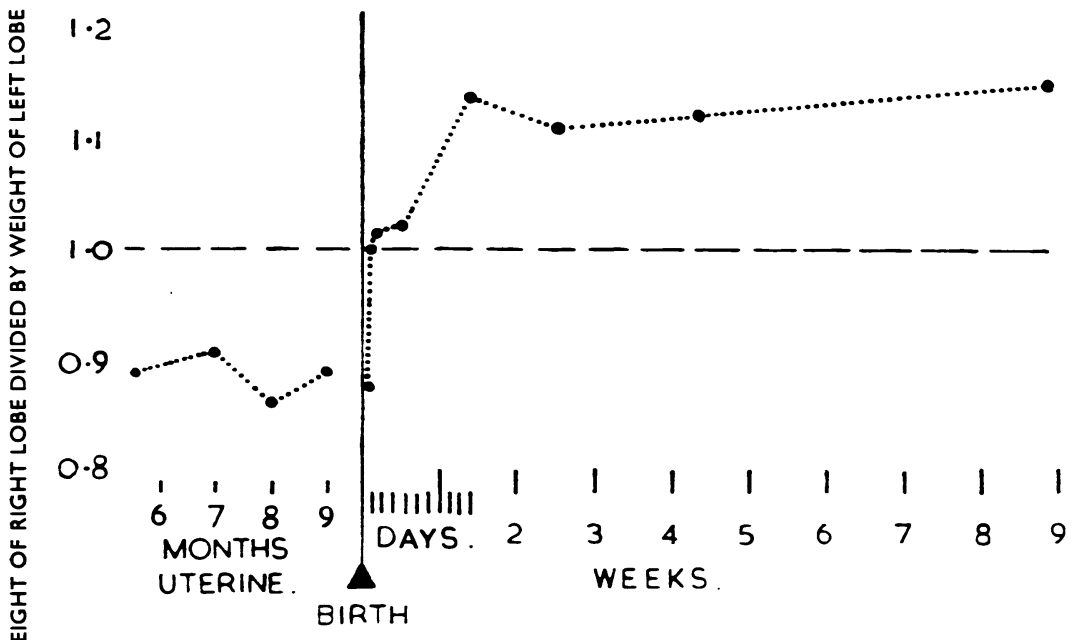

FIG. 1.-Graph showing the relationship of the ratio of the left and right livers to age in the newborn period.

\section{Discussion}

Taken in conjunction with the previous observations (Emery, 1952) of microscopic evidence of degeneration of parenchymal cells in the left liver, it seems that we have irrefutable evidence that following birth there is a rapid involution of the left liver. This involution is apparently completed by the end of the first week of extra-uterine life. The delay of about 12 hours after birth for gross changes in weight of the left liver to be seen seems to be simply a lag between the onset of degeneration and the gross evidence of its occurrence.

Much of the literature relating to the vascular changes occurring at birth has been discussed previously in connexion with the microscopic evidence of cell degeneration in the liver (Emery, 1952), and this will not be repeated here. In brief, the change seems to be directly consequent upon two factors, one, the sudden cessation of perfusion of the left liver by blood direct from the placenta, and second, the transitory persistence after birth of patency of the ductus venosus which permits the temporary existence of a potential Eck fistula. Of these two factors the first is of predominant importance.

Blackfan (1933) in the White House Report states that the involution of the left liver takes place before birth. Arey (1946) remarks, concerning the late intra-uterine state, that "in certain regions the hepatic tissues undergo degeneration (due to pressure atrophy) and especially is this true of the left lobe'. These statements are probably based upon measurements of the livers of mature stillborn infants before the fatty and hydropic changes consequent upon intra-uterine anoxia (Gruenwald, 1949) were realized.
The finding in the present series that the livers in the first few hours of life are similar to those before birth suggests that the changes in the left livers are postnatal and due to changes occurring at birth.

Ruge (1908), in discussing the external morphology of the foetal liver, noted that the left anatomical lobe was within a centimetre of the size of the right anatomical lobe, and that after birth the left lobe became smaller. Keibel and Mall (1912) noted a temporary relative decrease in the size of the whole liver at birth, i.e. a temporary interruption of the growth of the liver. They considered, as do others, that the changes in the size of the lobes of the liver were due to the pressure of adjacent organs, in particular the stomach. This explanation does not seem likely, as it is difficult to imagine how the pressure of different freely movable organs within the abdominal cavity could be different in different parts of the lower surface of the liver.

TABLE 2

NUMBER OF LIVERS IN DIFFERENT AGE GROUPS RELATED TO SIZES OF PHYSIOLOGICAL LEFT AND RIGHT LOBES

\begin{tabular}{|c|c|c|c|}
\hline & $\begin{array}{l}\text { Immature } \\
\text { Stillborns }\end{array}$ & $\begin{array}{l}\text { Birth to } \\
12 \text { Hours }\end{array}$ & $\begin{array}{l}25 \text { Hours to } \\
12 \text { Weeks }\end{array}$ \\
\hline $\begin{array}{c}\text { Livers with } R \text {.:L ratio greater } \\
\text { than } 1\end{array}$ & 3 & 4 & 53 \\
\hline $\begin{array}{cccc}\text { Livers with } & \text { R.:L. ratio less } \\
\text { than } 1 & \ldots & \ldots & \\
\end{array}$ & 16 & 10 & 11 \\
\hline $\begin{array}{cccc}\text { Total number of livers in } & \text { in } \\
\text { group } & \ldots & \ldots & \ldots\end{array}$ & 19 & 14 & 64 \\
\hline $\begin{array}{l}\text { Percentage of group with } R \text {. } \\
\text { liver greater than } L \text {. liver }\end{array}$ & $15 \cdot 7$ & $28 \cdot 6$ & $82 \cdot 8$ \\
\hline
\end{tabular}

The chief interest in the involuting changes in the newborn lies in the relationship to the production of physiological icterus. Our knowledge of physiological icterus has recently been well discussed by Smith (1951). He appears compelled to consider what is in effect 'physiological immaturity' of the liver as the major factor, and the statement by Davidson, Merritt and Weech (1941) that the degree of hyperbilirubinemia is a measure of the functional maturity of the infant at the time of 
birth' he refers to as the 'omega' of our present knowledge.

It can hardly be without significance that the same period after birth, i.e. about 100 hours, when the left liver is in a state of partial necrosis, is exactly the same as Yudkin, Gellis and Lappen (1949) found by bromsulphalein excretion tests when the liver showed its most grossly impaired function. The acute involution of the left liver after birth seems to be a reasonable explanation of the transitory inadequacy of the liver seen in the first few days of life. This would provide the most satisfactory explanation available at the moment of the postnatal rise in the bilirubin level and of the development of jaundice after birth.

Although the details of the mechanism do not appear to have been studied, the idea that icterus neonatorum is related to circulatory changes in the liver is by no means new. The following extract from a translation of a treatise on 'Disease of the Liver' by Frerichs (1860) written almost a hundred years ago is relevant.

The mode of production of icterus neonatorum in ordinary cases must be sought for in the diminished tension of the hepatic tissues, which takes place upon the stoppage of the influx of blood from the umbilical vein.'

The post-natal vascular changes in the liver will not explain the presence in a number of infants of a raised bilirubin level in the cord blood at the moment of birth (Davidson et al., 1941). A raised bilirubin level in the cord blood is known to be associated with an enhanced post-natal rise in bilirubin level and thence with an increased incidence of clinical icterus. In many instances physiological icterus follows a normal bilirubin level in the cord blood and thus there seem to be two separate factors, one post-natal and the other ante-natal. The most likely site of the ante-natal factor is the placenta. It is known that placental changes affect the foetal liver (Gruenwald, 1949) and Williamson (1923) found an increase in placental iron parallel with the increase in bilirubin in the cord blood. This aspect is at present under investigation and will be reported later.

\section{Summary}

There is a rapid involution of the left lobe of the liver beginning just after birth and completed within four or five days of birth.

This involution seems to be the direct result of changes in blood supply to the liver associated with birth.

The involution of the left liver coincides with the known period of deficient functional activity of the liver in the newborn. It is probably the cause of the temporary hepatic inadequacy during the first few days of life, hence the cause of the post-natal rise in bilirubin level associated with physiological icterus.

It is a pleasure to be able to acknowledge the courtesy of Dr. Warrack, in permitting facilities for much of the material reported in this study, and Miss C. Roseman for help with statistical interpretation.

\footnotetext{
ReFERENCES

Arey, L. B. (1946). Developmental Anatomy, 5th ed., p. 230.

Blackfan, K. D. (1933). Growth and Development of the Child, Pt. II, p. 409 . New York.

Cantlie, J. (1898). J. Anat., Lond., 32. p. iv.

Davidson, L. T., Merrit, K. K. and Weech, A. A. (1941). Amer. J. Dis. Child. 61, 958.

Emery, J. L. (1952). Archives of Disease in Childhood, 27, 558.

Frerichs, F. T. (1860). A Clinical Treatise on Diseases of the Liver, vol. i, p. 139. Translated by C. Murchison for New Sydenham Society, London.

Gruenwald, P. (1949). Amer. J. clin. Path., 19. 801.

Keibel, L. and Mall, F. P. (1912). Manual of Human Embryology, vol. 2, p. 426. London.

Mall, F. P. (1906). Amer. J. Anat., 5, 227.

Ruge, G. (1908). Morph. Jb., 37, 397.

Ruge, G. (1908). Morph. Jalkins, L. A. (1929). Growth in the Fetai Period. Minneapolis.

Smith, C. A. (1951). The Physiology of the Newborn Infant, 2nd ed., p. 81. Oxford.

Streeter. G. L. (1920). Contr. Embryol. Carneg. Instn, 11, 143. (No. 55.)

Williamson, A.C. (1923), Surg. Gynec, Obstet., 37, 57.

Yudkin, S., Gellis, S. S. and Lappen, F. (1949). Archives of Disease in Childhood, 24, 12.
} 